\title{
A-IV-3 重症僧帽弁狭窄症の手術適応と成績
}

\section{名古屋大学 第 1 外科 \\ 田中 稔 竹内 栄二 野垣 英逸 川村 光生 村瀬 允也 阿部 稔雄 弥政洋太郎}

僧帽弁狭窄症 (MS) の外科治療は，心筋保護法の進歩 とともに次第に手術適応が搪大され，内科治療の限界之 思われる症例でも，手術により救命し社会復帰が可能と なってきた．しかし，外科治療によって全例救命される 訳ではなく，不幸な転帰をとる場合もあり，手術適応に も限界があるものと思われる。このよらな外科治療の限 界を探るべく，当教室において一定した心筇保護法で手 術を行った MS 症例の手術成績, 術後心機能の改善の 様子を, 術前左心機能低下例を中心に検討した.

\section{対象および方法}

昭和 54 年以後, 当教室に和いて直視下手術を行った MS 症例は, 83 例である. 年令は, 34〜65 才で, 手術 術式は, 直視下僧帽切開術 60 例, 僧帽弁置換術 (MVR) 23 例である. 同時汇行われた合併手術は，大動脈弁置 換術 (AVR) が 6 , 大動脈冠動脈バイパス (A-C bypass) 術が 3 ，三尖弁弁輪形成術 (TAP) が 14 である。術前 心機能と術後成績の検討には，AVR を行った症例を除 外した 77 例を対象とした. 術前の心機能としては，心 臓カテーテル検查の結果から, 左室拡張期圧 (LVEDP),
左室拡張終期容量 (LVEDVI), 左室駆出率 (LVEF), 心俰数 $(\mathrm{CI})$ を，心エュー図から左室内径短縮率 (FS) を検討した。

\section{結果}

手術成績は，77 例中術後 30 日以内の手術死亡が 3 例, 遠隔死亡が 3 例である。 術前の LVEDVI $\geqq 100 \mathrm{~m} l / \mathrm{m}^{2}$ の症例は 11 例で, 術前平均值 $114.9 \pm 17.0$ (平均值士 標準偏差) $\mathrm{m} l / \mathrm{m}^{2}$ から, 術後 $89.0 \pm 19.7 \mathrm{~m} l / \mathrm{m}^{2}$ と対応 のある症例では有意に縮小した。 この中には，手術死亡， 遠隔死亡がおのおの 1 例ずつあった．手術死亡の 1 例は， MVR+A-C bypass 術を行った症例であり, 遠隔死亡 は, 術前 LVEDVI $106 \mathrm{~m} / / \mathrm{m}^{2}$ で MVR+A-C bypass 術+TAP を行い, 術後 LVEDVI $126 \mathrm{~m} l / \mathrm{m}^{2}$, LVEDP $25 \mathrm{mmHg}$ で退院し，3 カ月後に突然，死亡した（図 1).

術前 LVEDVI $\geqq 60 \mathrm{~m} l / \mathrm{m}^{2}$ の症例は 6 例あり，術前 $51.2 \pm 6.43 \mathrm{~m} l / \mathrm{m}^{2}$ から術後 $60.2 \pm 8.3 \mathrm{~m} l / \mathrm{m}^{2}$ 之堌大傾 向がみられた。この 6 例中に， 1 例の低心拍出症候群 (LOS) を原因とする死亡があった（図 1).

術前の LVEDP $\geq 10 \mathrm{mmHg}$ の症例は 23 例で, 術前
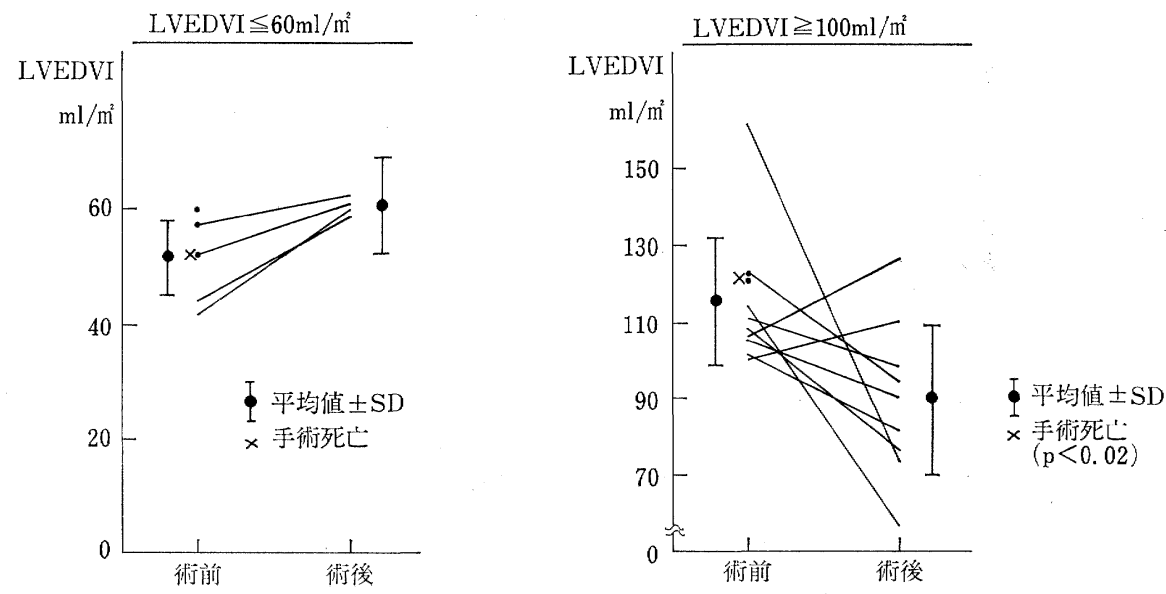

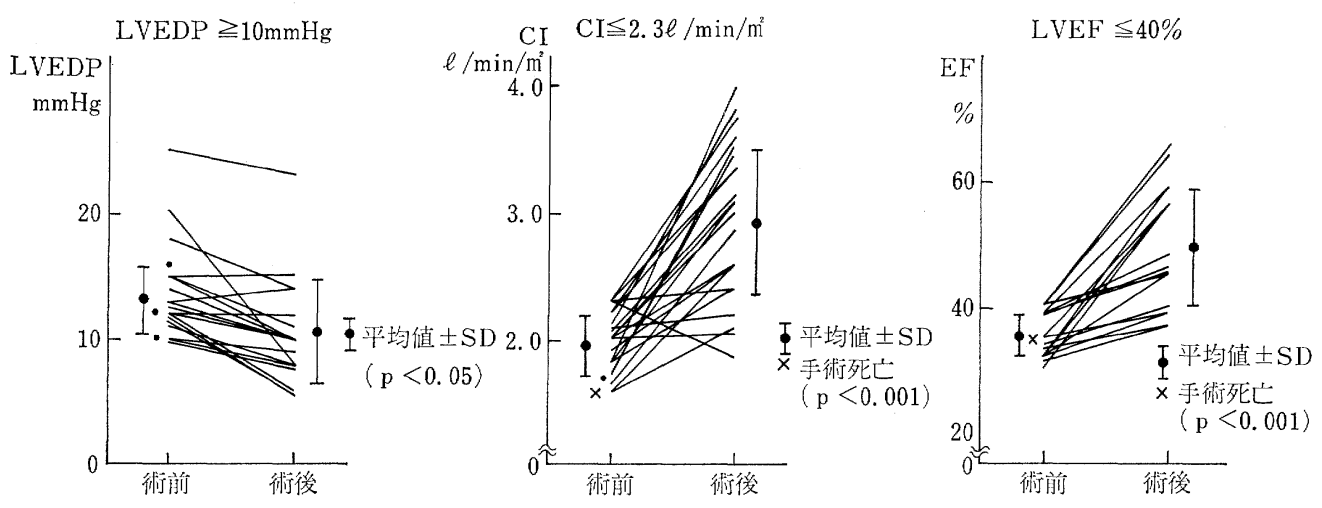

図 2

平均值 $13.0 \pm 2.69 \mathrm{mmHg}$ から, 術後 $10.4 \pm 4.03 \mathrm{~mm}$ $\mathrm{Hg}$ と有意に低下した. 23 例中，遠隔死亡が 1 例あるが， 手術死亡はなかった（図 2 ).

術前の $\mathrm{LVEF} \geqq 40 \%$ の症例は 16 例岁り，術前平均 值 $35.2 \pm 3.40 \%$ から，術後 $48.7 \pm 9.19 \%$ と有意に改 善した. 術前 LVEF の最低值は $31 \%$ で,この症例は 術前 NYHA 心機能分類 class IVで MVR+TAPを行 い, 術後 1 カ月の心蔵カテーテル検査では LVEF $37 \%$, CI $3.1 \mathrm{l} / \mathrm{min} / \mathrm{m}^{2}$ となり NYHA class I に改善した。 この群には，1例の手術死亡と，2例の遠隔死亡があっ た(図 2).

心エコー図法による $\mathrm{FS} \geqq 23 \%$ の症例を抽出し検討し てみた。この群には 19 例が含まれ，術前 $18.7 \pm 2.5 \%$ から, 術後 $24.0 \pm 6.4 \%$ と有意の増加が認められ, 手術 死亡が 1 例，遠隔死亡が 1 例あった。

術前の $\mathrm{CI} \geq 2.3 \mathrm{l} / \mathrm{min} / \mathrm{m}^{2}$ の症例は 24 例あり, 術前 $1.95 \pm 0.23 l / \mathrm{min} / \mathrm{m}^{2}$ から, 術後 $2.92 \pm 0.59 l / \mathrm{min} / \mathrm{m}^{2}$ と有意に堌加した。この中には，手術死亡 1 例，遠隔死 亡1例がみられた。な拉，術前 CI の最低值は，1.6l $\mathrm{min} / \mathrm{m}^{2}$ の症例が 3 例市り, 各症例とも術後 $2.0 \mathrm{l} / \mathrm{min} /$ $\mathrm{m}^{2}$ 以上に改善した（図 2 ).

\section{考察}

ここに 検討した 術前左心機能のらち， LVEDVI $\leqq 60$ $\mathrm{m} l / \mathrm{m}^{2}$ の症例は, 術後增加傾向を示し, 他の指標は, 手
表 1

\begin{tabular}{lcllll}
\hline & 症例数 & 手術死亡 & \multicolumn{1}{c}{ IABP } & 遠隔死亡 \\
\hline 総 数 & 77 & $3(3.9 \%)$ & $6(7.8 \%)$ & $3(3.9 \%)$ \\
$\mathrm{LVEDP} \geqq 10 \mathrm{mmHg}$ & 23 & 0 & $1(4.3 \%)$ & $1(4.3 \%)$ \\
$\mathrm{LVEDVI} \leqq 60 \mathrm{~m} l / \mathrm{m}^{2}$ & 6 & $1(17 \%)$ & $1(17 \%)$ & $1(17 \%)$ \\
$\mathrm{LVEDVI} \geqq 100 \mathrm{~m} / / \mathrm{m}^{2}$ & 11 & $1(9 \%)$ & 0 & $1(9 \%)$ \\
$\mathrm{LVEF} \leqq 40 \%$ & 16 & $1(6.2 \%)$ & $1(5.6 \%)$ & $2(12.5 \%)$ \\
$\mathrm{FS} \leqq 23 \%$ & 19 & $1(5.6 \%)$ & 0 & $1(5.6 \%)$ \\
$\mathrm{CI} \leqq 2.31 / \mathrm{min} / \mathrm{m}^{2}$ & 24 & $1(4.2 \%)$ & 0 & $2(8.3 \%)$ \\
$\mathrm{TAP}$ & 13 & 0 & $1(7.7 \%)$ & $3(23.1 \%)$ \\
$\mathrm{AC}-$ bypass & 3 & $1(33 \%)$ & $2(66 \%)$ & $1(33 \%)$ \\
\hline
\end{tabular}

術生存例では術後有意に改善した。しかし，ここに選択 した指標は，重症例と軽症例を分別する值が必ずしも決 定しているわけではなく，ぞの辺に境界を設定するかが 問題となる.このよらな問題点を考慮の中に入れ，それ ぞれの指標を総合的に評価して，各症例の重症度を判定 しなければならないが，今回の検討では LVEDP 以外 の指標の中に, 手術死亡・遠隔死亡の多い傾向が見られ た.しかしこのよらな指標よりも，A-C bypass 術や TAP 等の合併手術を必要とする症例の中に, 手術死亡 ・遠隔死亡・術後 IABP を必要とする LOS 発生例が 多く，僧帽弁以外の多岐にわたる手術を必要とする症例 の手術敊よび術後に注意を要するものと考学られる（表 $1)$. 